\title{
Investors' rationality. An analysis of the investment policy implications on shares valuation
}

\author{
Andreea CURMEI-SEMENESCU \\ Department Of Finance And CEFIMO, Faculty Of Finance And Banking, The Bucharest \\ University Of Economic Studies, Bucharest, Romania \\ andreea.semenescu@fin.ase.ro \\ Elena Valentina ŢILICĂ \\ Department Of Finance And CEFIMO, Faculty Of Finance And Banking, The Bucharest \\ University Of Economic Studies \\ elena.tilica@fin.ase.ro
}

Cătălin Valeriu CURMEI

UNESCO Department For Business Administration, Faculty Of Business Administration In

Foreign Languages, The Bucharest University Of Economic Studies, , Bucharest, Romania

catalin.curmei@fabiz.ase.ro

\begin{abstract}
The investment policy is an important vehicle of growth for a company. Therefore, it should be one of the most important signals for investors on the capital market. We use the statistical analysis of the investors' reactions to different patterns of investment policy to highlight their preference for an active investment policy and the changes induced by the financial crisis. By a comparative analysis of investors' preferences with the information on the accounting-based performance recorded simultaneously and in the future economic exercise, we focus on the extent and limits of the investors' rationality around the financial crisis.
\end{abstract}

Keywords: Investors' Rationality, Animal Spirits, Investment Policy

\section{Introduction}

The global financial crisis of 2008 opened a large field of debate between academics regarding its causes, "symptoms" and mitigating strategies. It also questioned the ability of the regulatory institutions to prevent such phenomena with terrible consequences on the real economic activity. In the scientific domain, it imposed the verification of the usual paradigms on agents' economic behavior.

On the capital market, the economic crisis led to a generalized drop in the prices of financial assets and a sharp decline of investors' confidence. Investors' sentiment became the core theme of a wide literature dealing with the study of the financial crisis (see the exposition of Akerlof and Shiller, 2009). It also opens the way for the investigation of the degree of investors' rationality in explaining their decisions, along with the financial characteristics of the issuers.

Our work goes in this direction, in the sense that we verify the hypothesis of capital markets investors' rationality. It aims to observe the degree of investors' rationality before, during and after the financial crisis, in correlation with the investment policy of the companies. First, we start by describing the preference of the capital market for an aggressive investment policy as opposed to a prudent one. Then, we examine the degree of 
investors' rationality by taking into account the quality of the issuers, including their accounting-based rates of return in the analysis.

The contribution of this study can be anticipated twofold. From a scientific point of view, it verifies the assumption of investors' rationality during the global financial crisis and suggests its possible limitations. This can be very useful for further researches in the field, given that investors' rationality is an important hypothesis for a number of economic models. From a practical perspective, the conclusions of our research may be of great importance for financial analysts in order to better understand the rationale behind the changes in the prices of the financial assets. They also offer a clue for the companies' management team to understand the effects that different investment policies could have in investors' eyes. Last, but not least, the study covers more than 60 countries, offering a realistic global picture, that includes companies from different domains.

The remaining of the study is organized as follows. Section 2 presents a brief literature review on the topic of the role of investors' sentiment during the financial crisis and on the importance of the investment policy in shaping investors' assessment about the financial soundness and perspectives of a company. Section 3 presents the methodology and database of the study. In section 4, the main results are discussed and section 5 concludes.

\section{Literature review}

The financial literature dedicated numerous works to the change of the investors' behavior during unstable periods. Akerlof and Shiller (2009) put the animal spirits in the center of their descriptive work on the propagation of the crisis and link this concept to subjective psychological factors that appear among the investors and lead to an overvaluation of the financial instruments before the crisis, followed by an intense pessimism after the start of the crisis, both phenomena leading to mispricing the financial assets, but in opposite directions. The same idea of psychological factors leading to irrational behavior is put forward by Prentice (2007) who considers that these factors ultimately lead to wrong financial decisions.

Chau et al. (2011) explain that investors' sentiment influences their market behavior in terms of increases or decreases of the risk-aversion and too optimistic or too pessimistic expectations. Therefore, the manifestation of the investors' sentiment will lead to different prices of the assets than those determined exclusively by taking into account changes in the fundamental valuation factors. Also, Hofmann et al. (2013) show that during financial crises the investors' risk tolerance decreases and their predictions become more pessimistic. On the other side, the authors mention that they found no evidence of a decrease of the market turnover or of the individual risk of private portfolios during turbulent periods.

The unstable financial environment is also linked in the financial literature to the efficiency of the financial markets. Lim et al. (2008) concluded that the efficiency of the capital market is weak before crisis, becomes even weaker during the crisis as a consequence of the investors' inability to adapt to the new conditions and increases significantly after the worst of the financial crisis passed. The same idea emerges from the study of Dragotă et al. (2009) for the Romanian capital market case and Dragotă and Țilică (2014) for a group of European emergent markets. 
Verma and Soydemir (2009) show that an optimistic generalized sentiment is related to a smaller market price of risk and the trend maintains as long as the predictions on the market remain optimistic. This may be a good explanation for the generalized decrease in the risk-aversion before the emergence of a crisis, in the so-called riskaccumulation period.

A very interesting and simple idea is in the center of the work of Lamont and Stein (2006) who remark that the most visible manifestation of the turbulences on the capital market is a generalized fluctuation of the share prices. Therefore, they propose as indicator measuring the investor's sentiment the aggregate price-to-book value on the market. The same paper also seeks the implications of the investors' sentiment in corporate finance decisions and brings arguments in favor of the idea that the investors' sentiment influences strategic decisions such as mergers and acquisitions and share issuance.

Our paper adds to the literature linking investors' sentiment to corporate strategic decisions, focusing on the particular aspect of capital budgeting decisions and how they are received by the investors on the capital market. Based on the conclusions of the studies mentioned above, we can expect that the investment policy of a company is linked to the investors' perception reflected in the market price of the shares. However, the direction of this relationship is unclear in the sense that the uncertainty of the previsions can induce a higher level of the risk perceived by the investors, but an active investment policy can also represent a positive signal for the investors showing that the company has investment opportunities and hence, better perspectives (Berk \&DeMarzo, 2011). In other words, De Jong et al. (2007) mention that high share prices create a pressure on the management to continue the expansionary policy and ultimately make managers take higher risk levels.

In our research design, we controlled for the accounting performance of the company as a way of overcoming this problem, when analyzing the investor preference for an active investment policy, also extracting interesting conclusions regarding the investors' rationality.

In the philosophy of the present study, the notion of "investors' rationality" is understood as the investors' ability of making correct valuation of the financial instruments based only on the fundamental factors related to the corporate management and the position of the company on the market. The investors' sentiment is considered to be responsible for the depart of the prices from their fundamental values due to non-financial influences. The manifestation of the investors' sentiment is therefore understood as a form of irrationality.

Following the reasoning of Lamont and Stein (2006), the aggregate price/book value represent an indicator of the market sentiment as it increases significantly in risk accumulation periods and decreases dramatically at the beginning of an economic depression. It is important for the reader to keep in mind that an increase of the aggregate price/book value on a market is linked to a form of generalized optimism, while the significant reduction of the same indicator is due to a generalized pessimism. However, the reader must bear in mind that the price/book value indicator varies according to a wide range of factors affecting the market- market conditions and regulation, investors' sentiment etc. - , but also the company and its future development - the intrinsic fundamental factors. (see Dragotă et al., 2012). Among the fundamental factors one may include a lot of issuer's characteristics such as: the assets belonging to the company, their quality and their structure, the human capital, the managerial skills etc. The profitability of 
the company and the return generated from its activity represent the reflection of how the resources in the company are put to work in order to increase the shareholders' wealth. Therefore, the return provided by the company should be an important criterion used by the investors in their decisions.

As mentioned by Brealey et al. (2001), the investors buy shares considering the present return provided by the company, but also its ability to generate incomes in the future, the investors having a long-term perspective. The perspectives of the companies to generate profits are shaped by the ability of the present assets to efficiently produce, but also the opportunities for the company to realize efficient investments in the future. From this perspective, the investors should also be interested in the capital budgeting decisions of the companies they invest in.

This is why the present study focuses on the capital budgeting policy of the listed companies and how it affected the investors' preferences before, during and after the emergence of the financial crisis. The main assumption used refers to the fact that the price to book value is influenced by the investment policy in a company, but also on its current functioning controlled by the accounting-based rates of return. On the other side, the price/book value is also determined by the investors' sentiment which allows us making interesting analyses regarding the extent and limits of the investors' rationality during the financial crisis.

\section{Database and methodology}

Our database contains companies from 82 countries and regions for the period 2006-2010. The data was obtained from Datastream and includes all the companies available on Datastream listed in the most important national equity indices. A list of the indices chosen is presented in the Appendix.

The database was refined as to eliminate the possible erroneous recordings (such as negative or null values for total assets, net sales, debt or market capitalization or negative capital expenditures). Additionally, companies with negative equity were eliminated so that our results are not impacted by companies in distress. Finally, we chose to exclude young companies from the database as they are expected to have an active investment policy due to their development phase, not as an option of strategic investment. We considered that being listed in the main national equity index for five years consecutively (the whole analysis period of 2006-2010) was proof of the maturity of a company. Hence, we have as a start point a database containing 5402 companies with financial information recorded for each of the years from 2006 to 2010. Finally, we remove the observations with missing data for either of the main indicators used in our analysis.

The main indicators used are Capital expenditure (as percentage of total assets) and Price/Book value $(\mathrm{P} / \mathrm{Bv})$. Capital expenditure characterizes a company's investment policy as it represents the money paid by the company to acquire non-current assets. By using it as percentage of total assets, we control for the size effect and insure a comparability across all companies. $P / B v$ is linked to the investors' opinion regarding a company's perspectives (see, among others, Fama \& French, 2007) in efficient markets. Thus, a company with an aggressive investment strategy, provided that the investments are economically valuable, should have a higher $\mathrm{P} / \mathrm{Bv}$. However, in turbulent periods, the 
efficiency of the market tends to decrease as mentioned in the literature review above and the price/book value could be influenced by investors' sentiment.

The companies included in the database were divided in two classes by comparing their capital expenditure/total assets with the one of their activity sector, regardless of the capital market on which the issuer is listed: the ones with an aggressive investment policy (above their activity sector) and those with a moderate one (below their activity sector). In our opinion, a company's investment policy is determined mainly by the activity sector, with its specificities, and in to a lesser extent by the country of origin.

In order to study investors' expectations, we divided the companies in two classes, based on their national $\mathrm{P} / \mathrm{Bv}$ : the ones with a high $\mathrm{P} / \mathrm{Bv}($ above the national one) and those with a low $\mathrm{P} / \mathrm{Bv}$ (below the national one). We chose to determine the national average of the $\mathrm{P} / \mathrm{Bv}^{1}$ because our database includes both developed and emerging capital markets and this approach allows us to separate the effect of the financial crisis which is, presumably, different from one country to another.

The last part of our paper, studies if investors' preferences are driven by rationality. For this, we examined if their decisions take into account the accounting-based rates of return as performance measures: return on equity (ROE) and return on assets (ROA). ROE is determined as Net Profit divided by Shareholders' equity and ROA is computed as follows:

$$
R O A=\frac{\text { Earnings before interest and taxes }- \text { Income tax payable }}{\text { Shareholders'equity }+ \text { Financial debt }}
$$

The companies were divided in classes: the ones with a higher return than the average rate of their activity sector and the ones with lower returns. Our choice for sector averages is based on the expected differences in return between them. The extent to which the companies preferred by investors accomplish the criteria regarding the type of investment policy and the profitability gives a picture of the interference of the irrationality in investors' decisions.

\section{Results}

\section{The market preference for investments}

First, we divided our observations into 4 categories, based on their relationship with the thresholds previously determined: firms with an aggressive investment policy that have a high price/book value (category A) or a low one (category B) and firms with a prudent investment policy that have a high price/book value (category C) or low one (category D). Table 1 presents our findings at a global level.

Table 1. The investors' preference for an active investment policy of the issuer. The table presents the percentage of the firms with a certain type of investment policy (aggressive for $A$ and $B$ and prudent for $C$ and $D$ ) that have a price to book value above or below the sector average.

\begin{tabular}{|l|l|l|l|l|}
\hline Year & A & B & C & D \\
\hline $\mathbf{2 0 0 6}$ & $43,73 \%$ & $56,27 \%$ & $35,25 \%$ & $64,75 \%$ \\
\hline $\mathbf{2 0 0 7}$ & $44,87 \%$ & $55,13 \%$ & $35,52 \%$ & $64,48 \%$ \\
\hline
\end{tabular}

\footnotetext{
${ }^{1}$ In order to insure the relevance of the average, we computed it only for the countries and sectors for which there were at least five records per year.
} 


\begin{tabular}{|l|l|l|l|l|}
$\mathbf{2 0 0 8}$ & $47,50 \%$ & $52,50 \%$ & $35,87 \%$ & $64,13 \%$ \\
\hline $\mathbf{2 0 0 9}$ & $38,07 \%$ & $61,93 \%$ & $29,88 \%$ & $70,12 \%$ \\
\hline $\mathbf{2 0 1 0}$ & $43,74 \%$ & $56,26 \%$ & $34,74 \%$ & $65,26 \%$ \\
\hline
\end{tabular}

The results show that among the companies with an aggressive investment policy, only $43.73 \%$ were rewarded by the investors in 2005 with a price/book value above the sector average. This percentage had little variations from one year to another, except for the year 2009, corresponding to the worst period of the crisis, when it decreased to $38.07 \%$, but increased back in 2010. The comparison to the category $\mathrm{C}$ shows that investors value positively an active investment policy during turbulent periods, but an increase of the risk aversion may have probably affected the result in 2009 . The category D includes companies with a moderate investment policy and low price/book values. The percentage registered in this category is significantly higher than that in the class B, supporting the same idea. However, the fact that more than half of the companies with an active investment policy have low price/book values show either an incapacity of the investors to adapt to the changes in the economic environment, or that some other factors also count in investors' decisions.

\section{Investors' rationality in determining their preference for the level of investments}

Having as a start point the conclusion above, we verified if the investors' choice is in accordance with the rational predictions, when considering the accounting-based performance indicators in the same year compared to the sector average. The performance indicators were also considered in the subsequent year to verify if the investments were in fact profitable for the company. We expect that a performance above the average is a good signal for the investors, who can also hope in efficient investments made by the companies. The price/book value for those companies is expected to be higher than for the other. Of course, efficient investments are likely to be associated with above average returns in the subsequent year. The analysis was made separately for two performance indicators: return on equity (ROE) and return on invested capital (ROA)

Inside each class - A, B, C, D - presented in the previous section we made a separation between companies with both present performance and performance subsequent to the investment year above the sectorial average, included in a subclass called "Above" and all other companies included in a subclass named "Below".

Table 2.Percentage of companies in each class with return on equity above the average of the sector in both years. The table presents the percentage of the companies in the subclasses „Above” and „Below” in each class.

\begin{tabular}{|l|l|l|l|l|l|l|l|l|}
\hline \multirow{2}{*}{ Year } & A & \multicolumn{2}{l}{ B } & \multicolumn{2}{l|}{ C } & \multicolumn{2}{l|}{ D } \\
\cline { 2 - 10 } & Above & Below & Above & Below & Above & Below & Above & Below \\
\hline 2006 & $54,97 \%$ & $45,03 \%$ & $26,89 \%$ & $73,11 \%$ & $48,47 \%$ & $51,53 \%$ & $19,95 \%$ & $80,05 \%$ \\
\hline 2007 & $51,51 \%$ & $48,49 \%$ & $24,77 \%$ & $75,23 \%$ & $49,58 \%$ & $50,42 \%$ & $21,28 \%$ & $78,72 \%$ \\
\hline 2008 & $51,62 \%$ & $40,10 \%$ & $29,50 \%$ & $70,50 \%$ & $45,62 \%$ & $54,38 \%$ & $23,37 \%$ & $76,63 \%$ \\
\hline 2009 & $58,17 \%$ & $41,83 \%$ & $33,33 \%$ & $66,67 \%$ & $44,30 \%$ & $55,70 \%$ & $23,17 \%$ & $76,83 \%$ \\
\hline
\end{tabular}


Table 3.Percentage of companies in each class with return on invested capital above the average of the sector in both years. The table present the percentage of the companies in the subclasses "Above” and "Below” in each class.

\begin{tabular}{|l|l|l|l|l|l|l|l|l|}
\hline \multirow{2}{*}{ Year } & \multicolumn{1}{|l|}{ A } & \multicolumn{1}{l}{ B } & \multicolumn{2}{l|}{ C } & \multicolumn{2}{l|}{ D } \\
\cline { 2 - 10 } & Above & Below & Above & Below & Above & Below & Above & Below \\
\hline $\mathbf{2 0 0 6}$ & $52,11 \%$ & $47,89 \%$ & $25,45 \%$ & $74,55 \%$ & $42,74 \%$ & $57,26 \%$ & $20,45 \%$ & $79,55 \%$ \\
\hline $\mathbf{2 0 0 7}$ & $48,92 \%$ & $51,08 \%$ & $23,61 \%$ & $76,39 \%$ & $45,75 \%$ & $54,27 \%$ & $20,84 \%$ & $79,16 \%$ \\
\hline $\mathbf{2 0 0 8}$ & $53,18 \%$ & $46,82 \%$ & $28,84 \%$ & $71,16 \%$ & $42,30 \%$ & $57,70 \%$ & $23,04 \%$ & $76,96 \%$ \\
\hline $\mathbf{2 0 0 9}$ & $54,98 \%$ & $45,02 \%$ & $32,07 \%$ & $67,93 \%$ & $42,30 \%$ & $57,70 \%$ & $23,46 \%$ & $76,54 \%$ \\
\hline
\end{tabular}

The fact that more than half of the companies in the class A have performance indicators above the sector average in both years show that the investors' decision for these companies was correct and sustained by fundamental indicators. In the class B, only $25 \%-33 \%$ of the companies were reported to have performance indicators above the sector average in both years. However, for these companies, the investors did not manifest a preference though both performances and investment policies were above the sector average. It is also important to see that these percentage increases in 2008 and 2009, probably associated to an increase in the investors' pessimism.

The figures in the class $C$ are even more unexpected. It seems that more than half of these companies are valued highly by the market though they have a prudent investment policy and had lower returns at least in one year. The percentage maintains important (over 50\%) during the entire period. This high percentage seems to favour the explanation that the investors were not able to adapt their decision to the new paradigm and made erroneous decisions in a lot of cases, no matter the emergence of the crisis. This behaviour may be in the sense of avoiding making a "cut-the-loss" decision after the occurrence of the crisis for the fear of recognizing the previous bad decision. It may also have its roots in a short- term speculative investment horizon that can lead to maintaining the deviation of the prices from the fundamental value of the share. The percentage is significantly lower, as expected, for the firms in the subclass "Above" of the class D.

As the market manifested a preference for investments, we computed the percentage of the right or wrong decisions taken based on the investment policy of the companies and their return on equity (Table 4).

Table 4.Investor assesment of companies

\begin{tabular}{|c|c|c|c|c|}
\hline \multirow{2}{*}{ Year } & \multicolumn{4}{|c|}{ ROE } \\
\cline { 2 - 5 } & High investment & \multicolumn{2}{|c|}{ Low investment } \\
\cline { 2 - 5 } & Right & Wrong & Right & Wrong \\
\hline $\mathbf{2 0 0 6}$ & $65,17 \%$ & $34,83 \%$ & $68,92 \%$ & $31,08 \%$ \\
\hline $\mathbf{2 0 0 7}$ & $64,59 \%$ & $35,41 \%$ & $68,37 \%$ & $31,63 \%$ \\
\hline $\mathbf{2 0 0 8}$ & $61,53 \%$ & $34,54 \%$ & $65,50 \%$ & $34,50 \%$ \\
\hline $\mathbf{2 0 0 9}$ & $63,43 \%$ & $36,57 \%$ & $67,11 \%$ & $32,89 \%$ \\
\hline
\end{tabular}


The results do not differ much between the companies with an active investment policy and those with a prudent one. In general terms, the investors did not seem to have been fooled by the companies with aggressive investment policies.

A result that has however to be emphasized is that the investors made erroneous decisions in one third of the cases, which somehow prove that there is still place for improving their decision making. This high figure can be a clue for a possible influence of the investors' sentiment on the capital markets in the period right before and after the emergence of the financial crisis.

\section{Conclusions}

The global financial crisis questioned the degree of investors' rationality on the capital market. Using a large database including companies in more than 60 countries and a simple statistical analysis, we put in evidence the extent and the limits of investors' rationality. In order to obtain robust conclusions, we first study the investors' preferences for different patterns of capital budgeting adopted by the issuers around the period of the financial crisis. We confirm the hypothesis of their significant generalized pessimism in 2009, which coincides with the financial crisis, and the prudent behavior of the capital markets seems to maintain in 2010. As for the preference for an active investment policy, it regains the shape from before the financial crisis.

Additionally, we tried to determine if the investors use certain fundamental reasoning in order to determine their preference for high or low investments. Thus, we observed if their preference can be explained by taking into consideration the return of the company from the year when the investment took place and the one after that. The results show that most cases can be explained in this way, which is a signal for the rational behavior of these investors. However, the percentage is decreasing in time.

The cases that cannot be explained are also relatively high (more than $30 \%$ ). This means that in a high number of cases the investors did not take into account the implications of the investment policy on the company or that their predictions were wrong. Based on our results, we cannot deny that some investors appear to have a reasoning based on rational criteria linked to a company's investment policy. However, there are some signals on the market that show some limits of the rational behavior on the global market.

As further directions of study, we think it might be useful to see if these signals are similar in different types of countries (based on geographical location, level of development, etc). This might show us if investors' preference for a specific capital budgeting strategy varies according to the specificities of the market the company is listed on.

\section{Acknowledgements}

We are grateful to the LAREFI laboratory of the University Montesquieu Bordeaux 4 for allowing us to obtain the data. We also thank prof. Victor Dragotă for very helpful comments.

\section{References}

Akerlof, G. \& Shiller, R. (2009). Animal Spirits: How Human Psychology Drives the Economy, and Why It Matters for Global Capitalism. Princeton, NJ: Princeton University Press.

Berk, J. \&DeMarzo, P. (2011). Finance d'Entreprise. Paris, France:Pearson Publishing House 
Brealey,R., Myers, S. \& Marcus, A. (2001). Fundamentals of Corporate Finance(3rd edition). New York, NY: McGraw-Hill Primis Custom Publishing.

Chau, F., Deesomsak, R. \& Lau, M. (2011).Investor sentiment and feedback trading: Evidence from the exchange-tradedfund markets.International Review of Financial Analysis,20, 292-305.

De Jong, A., DeJong, D., Mertens, G. \&Roosenboom, P. (2007).Investor relations, reputational bonding, and corporate governance:The case of Royal Ahold. Journal of Accounting and Public Policy, 26, 328-375.

Dragotă, V., Stoian, A., Pele, D., Mitrică, E. \&Bensafta, M. (2009).The Development of the Romanian Capital Market: Evidences on Information Efficiency. RomanianJournal of Economic Forecasting, 10 (2), 147-160.

Dragotă, V., Obreja Braşoveanu, L. \& Dragotă, I.M. (2012). Management financiar. Diagnosticul financiar al companiei (2nd edition).Bucharest, Romania: Economic Printing House, 245-254.

Dragotă,V. \& Ţilică, E. (2014).Market efficiency of the Post Communist East European stock markets.Central European Journal of Operations Research, 22, 307-337

Fama, E. \& French, K., (2007). The Anatomy of Value and Growth Stock Returns. Financial Analysts'Journal, 63 (6), 44-56.

Hoffmann, A., Post, T. \& Pennings, J. (2013).Individual investor perceptions and behavior during the financial crisis.Journal of Banking and Finance, 37, 60-74

Lamont, O.A. \&Stein, J.C.(2006).Investor sentiment and corporate finance: Micro and macro. The American Economic Review, 95, 147-151.

Lim, K., Brooks, R. \& Kim, J. (2008). Financial crisis and stock market efficiency: Empirical evidence from Asian countries, International Review of Financial Analysis, 17, 571591.

Prentice, R. (2007). Ethical Decision Making: More Need than Good Intuitions. Financial Analysts'Journal, 63 (6), 17-30.

Verma, R. \&Soydemir, G. (2009).The impact of individual and institutional investor sentiment on the market price of risk.The Quarterly Review of Economics and Finance, 49, 1129-1145.

www.worldbank.org accessed on February $5^{\text {th }} 2014$

\section{Appendix}

The table below inventories the countries, main financial indexes and number of companies in our basic sample. In the last columns we marked the countries which remain in our final database.

\begin{tabular}{|c|c|c|c|c|}
\hline No. & Country & Financial Index & $\begin{array}{l}\text { Number } \\
\text { companies }\end{array}$ & $\begin{array}{l}\text { Present in the final } \\
\text { database }\end{array}$ \\
\hline 1 & Argentina & Merval Constituents AR & 9 & Yes \\
\hline 2 & Australia & S\&P200 & 138 & Yes \\
\hline 3 & Austria & ATX & 14 & Yes \\
\hline 4 & Bahrain & DS-Market Constituents SBA & 21 & Yes \\
\hline 5 & Bangladesh & CO AC'S Worldscope & 29 & Yes \\
\hline 6 & Belgium & BEL20 & 16 & Yes \\
\hline 7 & BosniaHerzegovina & Banjaluka Research BP & 33 & Yes \\
\hline 8 & Botswana & Botswana All-Share & 12 & Yes \\
\hline 9 & Brasil & BOVESPA & 60 & Yes \\
\hline 10 & Bulgaria & Sofix Weighting & 10 & Yes \\
\hline
\end{tabular}




\begin{tabular}{|c|c|c|c|c|c|}
\hline 11 & Canada & S\&P TSX Composite & 180 & Yes & \multirow{51}{*}{ PICBE | 587} \\
\hline 12 & Chile & IGPA Constituents CL & 84 & Yes & \\
\hline 13 & China & Shanghai All-Share index & 788 & Yes & \\
\hline 14 & Cyprus & CO AC'S Worldscope Cyprus & 75 & Yes & \\
\hline 15 & Czech Republic & Prague SE PX & 10 & Yes & \\
\hline 16 & Denmark & OMX Copenhagen & 103 & Yes & \\
\hline 17 & Egypt & Hermes financial & 34 & Yes & \\
\hline 18 & Estonia & CO AC'S Worldscope Estonia & 15 & Yes & \\
\hline 19 & Finlanda & OMX Helsinki & 108 & Yes & \\
\hline 20 & France & CAC-40 & 35 & Yes & \\
\hline 21 & Germany & DAX & 25 & Yes & \\
\hline 22 & Ghana & Ghana reserch GH & 19 & Yes & \\
\hline 23 & Greece & Athex composite index & 55 & Yes & \\
\hline 24 & Hong Kong & HANG SENG Index & 39 & Yes & \\
\hline 25 & Hungary & BUX & 7 & Yes & \\
\hline 26 & Iceland & OMX Iceland All-Share & 5 & No & \\
\hline 27 & India & BSE 100 & 76 & Yes & \\
\hline 28 & Indonesia & Jakarta Composite & 315 & Yes & \\
\hline 29 & Ireland & ISEQ Overall Index & 29 & Yes & \\
\hline 30 & Israel & Israel All Share & 75 & Yes & \\
\hline 31 & Italy & FTSEMIB & 27 & Yes & \\
\hline 32 & Ivory Coast & Ivoary Coast Research & 20 & Yes & \\
\hline 33 & Jamaica & CO AC'S Worldscope Jamaica & 18 & No & \\
\hline 34 & Japan & Nikkei 225 & 197 & Yes & \\
\hline 35 & Jordan & $\begin{array}{l}\text { Aman Financial Market All share } \\
\text { Index }\end{array}$ & 46 & Yes & \\
\hline 36 & Kazakhstan & CO AC'S Worldscope Kazakhstan & 29 & Yes & \\
\hline 37 & Kenya & NSEI Index Constituents & 10 & Yes & \\
\hline 38 & Korea, Rep. & KOSPI 200 & 179 & Yes & \\
\hline 39 & Kuwait & DJIM Kuwait & 17 & Yes & \\
\hline 40 & Latvia & CO AC'S Worldscope Latvia & 29 & Yes & \\
\hline 41 & Lebanon & Lebanon Research & 5 & Yes & \\
\hline 42 & Lithuania & CO AC'S Worldscope Lithuania & 28 & Yes & \\
\hline 43 & Luxembourg & Luxembourg SE Luxx & 6 & No & \\
\hline 44 & Macedonia, Rep. & CO AC'S Worldscope Macedonia & 25 & Yes & \\
\hline 45 & Malaysia & FTSE Malaysia KCCI & 20 & Yes & \\
\hline 46 & Malta & CO AC'S Worldscope Malta & 13 & Yes & \\
\hline 47 & Mauritius & CO AC's Worldscope Mauritius & 33 & Yes & \\
\hline 48 & Mexic & Indice de Precios e Cotisatones & 32 & Yes & \\
\hline 49 & Morocco & LMASIIDX & 54 & Yes & \\
\hline 50 & Netherlands & Amsterdam 25 & 20 & Yes & \\
\hline 51 & New Zeeland & NZX 50 & 36 & Yes & \\
\hline 52 & Norway & Oslo Exchange All Share & 147 & Yes & \\
\hline 53 & Oman & Muscat SE General & 18 & Yes & \\
\hline 54 & Pakistan & KSE 100 Index & 61 & Yes & \\
\hline 55 & Palestinian Terr. & $\begin{array}{l}\text { CO AC'S Worldscope Palestinian } \\
\text { territory }\end{array}$ & 14 & Yes & \\
\hline 56 & Peru & Lima Selective & 10 & Yes & \\
\hline 57 & Philipines & Manila Composite Index & 26 & Yes & \\
\hline 58 & Poland & Warsaw General & 265 & Yes & \\
\hline 59 & Portugal & Portugal PSI All Share & 37 & Yes & \\
\hline 60 & Romania & BET composite & 52 & Yes & \\
\hline 61 & Russia & MICEX & 41 & Yes & \\
\hline
\end{tabular}

DOI: 10.2478/picbe-2019-0051, pp. 578-588, ISSN 2558-9652| Proceedings of the $13^{\text {th }}$ International Conference on Business Excellence 2019 


\begin{tabular}{|r|l|l|r|l|}
\hline 62 & Saudi Arabia & Saudi arabiaTadawul All share & 96 & Yes \\
\hline 63 & Serbia & CO AC'S Worldscope Serbia & 93 & No \\
\hline 64 & Slovakia & Reserch SX & 13 & Yes \\
\hline 65 & Slovenia & SBI Top Index & 5 & Yes \\
\hline 66 & South Africa & FTSE JSE All Shares & 134 & Yes \\
\hline 67 & Spain & IBEX35 & 26 & Yes \\
\hline 68 & Sri Lanka & CO AC'S Worldscope Sri Lanka & 150 & Yes \\
\hline 69 & Sweden & OMX 30 Stockholm & 24 & Yes \\
\hline 70 & Switzerland & Swiss Market Index & 16 & Yes \\
\hline 71 & Tanzania & Reserch TZ & 5 & No \\
\hline 72 & Thailand & Thailand SE & 360 & Yes \\
\hline 73 & Tunis & CO AC'S Worldscope Tunisia & 31 & Yes \\
\hline 74 & Turkey & ISE National 100 & 75 & Yes \\
\hline 75 & Uganda & Uganda All Sectors & 1 & No \\
\hline 76 & Ukrain & IBES DULIST & 22 & Yes \\
\hline 77 & United Arab Emirates & DFM General & 14 & Yes \\
\hline 78 & United Kingdom & FTSE 100 & 73 & Yes \\
\hline & United States of & S\&P500 & 294 & Yes \\
79 & America & General Sector Ve & 7 & Yes \\
\hline 80 & Venezuela & Zambia All Sectors & 11 & No \\
\hline 81 & Zambia & Zimbabwe All Share & 18 & No \\
\hline 82 & Zimbabwe & & \\
\hline
\end{tabular}

